\title{
Two New Sesquiterpene Lactones from Ixeris chinensis
}

\author{
Ashraf Taha KhaliL, ${ }^{a}$ Ya-Ching Shen, ${ }^{*}, a$ Jih-Hwa Guh, ${ }^{b}$ and Shi-Yie Cheng ${ }^{a}$ \\ ${ }^{a}$ Institute of Marine Resources, National Sun Yat-sen University; 70 Lien-Hai Road, Kaohsiung, Taiwan 80424, Republic \\ of China: and ${ }^{b}$ School of Pharmacy, College of Medicine, National Taiwan University; No. 1, Jen-Ai Road, Sect. 1, Taipei, \\ Taiwan Republic of China. Received May 26, 2004; accepted October 13, 2004
}

\begin{abstract}
Phytochemical investigation of Ixeris chinensis NAKAI (Asteraceae) has resulted in the isolation of a new guaianolide-type sesquiterpene lactone, ixerochinolide (1) as well as the related glucoside, ixerochinoside (2). In addition, the known guaianolides, 8 $\beta$-hydroxy-3-oxo-guaia-4(15),10(14),11(13)-trien-1 $\alpha, 5 \alpha, 6 \beta, 7 \alpha \mathrm{H}-12,6$-olide (8 $\beta$-hydroxydehydrozaluzanin), $\quad 8 \beta, 15$-dihydroxy-2-oxo-guaia-1(10),3,11(13)-trien-5 $\alpha, 6 \beta, 7 \alpha \mathrm{H}-12,6$-olide (lactucin), $3 \beta, 8 \alpha, 10 \alpha$-trihydroxy-guaia-4(15),11(13)-dien-1 $\alpha, 5 \alpha, 6 \beta, 7 \alpha \mathrm{H}$-12,6-olide (10 $\alpha$-hydroxy-10,14-dihydro-desacylcynaropicrin) and $3 \beta$-D-glucopyranosyloxy- $\beta \beta$-( $p$-hydroxyphenylacetyloxy)-guaia-4(15),10(14),11(13)-trien$1 \alpha, 5 \alpha, 6 \beta, 7 \alpha \mathrm{H}-12,6$-olide (8-epicrepioside) were identified. The structures were determined on the basis of spectral analyses, especially 1- and 2D NMR. Compound 1 exhibited significant cytotoxicity against human PC-3 tumor cells.
\end{abstract}

Key words Ixeris chinensis; Asteraceae; guaianolide; ixerochinolide; ixerochinoside; cytotoxic activity

Ixeris chinensis NAKAI (Asteraceae) is a medicinal Chinese herb used for treatment of bronchitis, pneumonia, dysentery as well as for its antipyretic, analgesic and anti-inflammatory effects. ${ }^{1)}$ As many Asteraceaous plants, this species is rich in sesquiterpene lactones with diverse biological activities ${ }^{2-4)}$ such as immunomodulator ${ }^{5)}$ and cytotoxic effects. ${ }^{6)}$ Their biological activities have been attributed to their reactivity with the cysteine residues of functional proteins forming covalent bonds. ${ }^{7)}$ Six guaianolides ${ }^{8,9)}$ in addition to forty triterpenoids $^{10,11)}$ were previously isolated from this species. The present study is concerned with the isolation and structural elucidation of two new guaianolides, ixerochinolide (1) and a related glucoside, ixerochinoside (2). During the course of fractionation, four known guaianolides, $8 \beta$-hydroxy-3-oxoguaia-4(15),10(14),11(13)-trien- $\alpha, 5 \alpha, 6 \beta, 7 \alpha \mathrm{H}-12,6$-olide (8$\beta$-hydroxydehydrozaluzanin), $8 \beta, 15$-dihydroxy-2-oxo-guaia1(10),3,11(13)-trien-5 $\alpha, 6 \beta, 7 \alpha \mathrm{H}-12,6$-olide (lactucin), $3 \beta, 8 \alpha$, $10 \alpha$-trihydroxy-guaia-4(15),11(13)-dien- $\alpha, 5 \alpha, 6 \beta, 7 \alpha \mathrm{H}$ 12,6-olide (10 $\alpha$-hydroxy-10,14-dihydro-desacylcynaropicrin) and $3 \beta$-D-glucopyranosyloxy- $8 \beta$-( $p$-hydroxyphenylacetyloxy)guaia-4(15),10(14),11(13)-trien-1 $\alpha 5 \alpha, 6 \beta, 7 \alpha \mathrm{H}-12,6$-olide (8-epicrepioside) were identified. The structures of these bitter-tasting compounds were elucidated through detailed studies of the spectral data especially 1- and 2D NMR. The cytotoxic activity of the isolated guaianolides was tested against human PC-3 tumor cells.

\section{Results and Discussion}

Chromatographic fractionation of the acetone extract of Ixeris chinensis NAKAI has led to the isolation of six guaianolide derivatives. The HR-ESI-MS of 1 revealed a quasi-molecular ion peak at $m / z 419.1474[\mathrm{M}+\mathrm{Na}]^{+}$consistent with the molecular formula $\mathrm{C}_{23} \mathrm{H}_{24} \mathrm{O}_{6}$ and twelve degrees of unsaturation. The IR spectrum showed absorption bands characteristic of a hydroxyl $\left(3405 \mathrm{~cm}^{-1}\right)$, lactone ring $\left(1767 \mathrm{~cm}^{-1}\right)$, ester $\left(1737 \mathrm{~cm}^{-1}\right)$ and double bond(s) $\left(1634 \mathrm{~cm}^{-1}\right)$. The ${ }^{1} \mathrm{H}-\mathrm{NMR}$ displayed signals at $\delta 6.10(\mathrm{~d}, J=3.1 \mathrm{~Hz})$ and $5.39(\mathrm{~d}$, $J=3.3 \mathrm{~Hz}$ ) suggesting the presence of an $\alpha$-methylene- $\gamma$-lactone ring. ${ }^{12)}$ Two pairs of olefinic singlets at $\delta 5.46,5.36$ and $5.06,4.81$ indicated the presence of two exomethylenes. The coupling constant $J_{1,5}, J_{5,6}$ and $J_{6,7}(9.6 \mathrm{~Hz})$ was in agreement with A,B cis-fused guaianolide skeleton with trans-diaxial disposition of H-6 $(\beta)$ and H-7 $(\alpha){ }^{13)}$ In addition, the COSY spectrum showed correlations between $\mathrm{H}-1 / \mathrm{H}-2, \mathrm{H}-5$; H-2/H3; H-5/H-6; H-7/H-6, H-8, H-13; and H-8/H-9. The presence of $p$-hydroxyphenylacetic acid ester was evident from the two aromatic $\mathrm{A}_{2} \mathrm{~B}_{2}$ signals at $\delta 7.01,6.76$ (each $2 \mathrm{H}, \mathrm{d}$, $J=8.2 \mathrm{~Hz}$ ) and a benzylic methylene singlet at $\delta 3.47 .{ }^{12,13}$ ) The ${ }^{13} \mathrm{C}$-NMR data (Table 1) supported the proposed structure through revealing signals for the guaianolide skeleton as well as the attached $p$-hydroxyphenylacetic acid ester. ${ }^{9)}$ The three oxygenated methines observed at $\delta 4.60,4.40$ and 5.43 were assigned to $\mathrm{H}-3, \mathrm{H}-6$ and $\mathrm{H}-8$ respectively. The relative

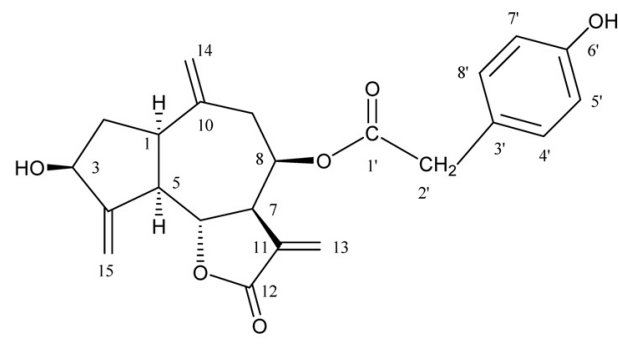

1

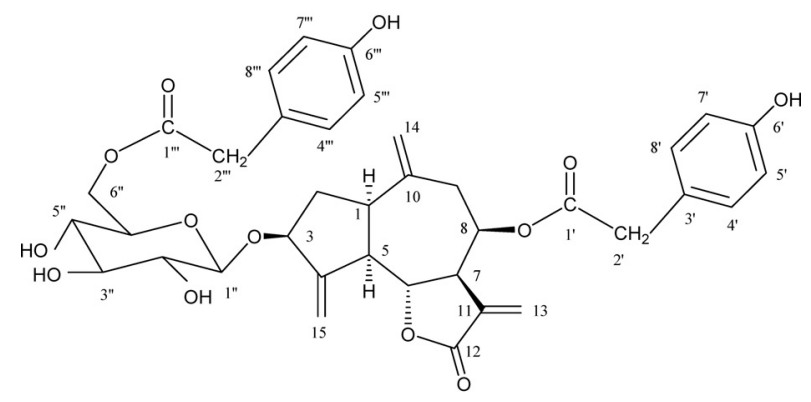

2 
Table $1 .{ }^{13} \mathrm{C}-\mathrm{NMR}$ Data of $\mathbf{1}$ and $\mathbf{2}^{a)}$

\begin{tabular}{|c|c|c|c|c|}
\hline C-atom & $\mathbf{1}^{b)}$ & $\mathbf{2}^{c)}$ & C-atom & $\mathbf{2}^{c)}$ \\
\hline 1 & 44.4 (d) & 45.2 (d) & $1^{\prime \prime}$ & 104.1 (d) \\
\hline 2 & $39.0(\mathrm{t})$ & $38.7(\mathrm{t})$ & $2^{\prime \prime}$ & $75.2(\mathrm{~d})$ \\
\hline 3 & $73.4(\mathrm{~d})$ & 81.9 (d) & $3^{\prime \prime}$ & 77.9 (d) \\
\hline 4 & $152.6(\mathrm{~s})$ & $150.9(\mathrm{~s})$ & $4^{\prime \prime}$ & 71.9 (d) \\
\hline 5 & $50.3(\mathrm{~d})$ & $50.8(\mathrm{~d})$ & $5^{\prime \prime}$ & 75.3 (d) \\
\hline 6 & 78.8 (d) & 80.3 (d) & $6^{\prime \prime}$ & $65.1(\mathrm{t})$ \\
\hline 7 & 48.3 (d) & 49.5 (d) & $1^{\prime \prime \prime}$ & $173.6(\mathrm{~s})$ \\
\hline 8 & 67.7 (d) & 69.3 (d) & $2^{\prime \prime \prime}$ & $41.2(\mathrm{t})$ \\
\hline 9 & $39.4(\mathrm{t})$ & $41.7(\mathrm{t})$ & $3^{\prime \prime \prime}$ & $126.3(\mathrm{~s})$ \\
\hline 10 & $142.1(\mathrm{~s})$ & $144.5(\mathrm{~s})$ & $4^{\prime \prime \prime}$ & $131.4(\mathrm{~d})$ \\
\hline 11 & $134.3(\mathrm{~s})$ & $136.7(\mathrm{~s})$ & $5^{\prime \prime \prime}$ & $116.3(d)$ \\
\hline 12 & $169.6(\mathrm{~s})$ & $171.4(\mathrm{~s})$ & $6^{\prime \prime \prime}$ & $157.5(\mathrm{~s})$ \\
\hline 13 & $122.4(\mathrm{t})$ & $122.2(\mathrm{t})$ & $7^{\prime \prime \prime}$ & $116.3(\mathrm{~d})$ \\
\hline 14 & $117.9(\mathrm{t})$ & $117.6(t)$ & $8^{\prime \prime \prime}$ & $131.4(\mathrm{~d})$ \\
\hline 15 & $111.7(\mathrm{t})$ & $112.2(\mathrm{t})$ & & \\
\hline $1^{\prime}$ & $171.1(\mathrm{~s})$ & $172.9(\mathrm{~s})$ & & \\
\hline $2^{\prime}$ & $40.9(\mathrm{t})$ & $41.4(\mathrm{t})$ & & \\
\hline $3^{\prime}$ & $125.3(\mathrm{~s})$ & $126.1(\mathrm{~s})$ & & \\
\hline $4^{\prime}$ & $130.4(d)$ & $131.3(\mathrm{~d})$ & & \\
\hline $5^{\prime}$ & 115.8 (d) & $116.2(d)$ & & \\
\hline $6^{\prime}$ & $155.4(\mathrm{~s})$ & $157.6(\mathrm{~s})$ & & \\
\hline $7^{\prime}$ & 115.8 (d) & $116.2(\mathrm{~d})$ & & \\
\hline $8^{\prime}$ & $130.4(d)$ & $131.3(\mathrm{~d})$ & & \\
\hline
\end{tabular}

a) Multiplicities were assigned from DEPT and HMQC spectra. b) Measured at $75 \mathrm{MHz}$ in $\mathrm{CDCl}_{3}$. c) Measured at $125 \mathrm{MHz}$ in $\mathrm{CD}_{3} \mathrm{OD}$.

downfield shift of H-8 ( $\delta$ 5.43) was attributed to the attachment of the ester moiety that was proved by HMBC correlation between H-8 and the carbonyl ester signal at $\delta 171.1$. Furthermore, the HMBC spectrum exhibited correlations between H-3/C-15; H-7/C-5, C-13; H-8/C-10; H-14/C-1. Contrary to the case of hydroxyl or $\alpha$-acyloxy substitution at $\mathrm{C}$ 8 , the minute coupling constant of $J_{7,8}(1.8 \mathrm{~Hz})$ implied the $\alpha$-configuration of both $\mathrm{H}-7$ and $\mathrm{H}-8$ that was in accordance with the results obtained from a molecular model. ${ }^{15-17)}$ The strong NOESY correlations between $\mathrm{H}-8 / \mathrm{H}-7 \alpha$ as well as between $\mathrm{H}-5 \alpha / \mathrm{H}-1, \mathrm{H}-3$ and $\mathrm{H}-7$ confirmed the $\alpha$-configuration of both $\mathrm{H}-8$ and $\mathrm{H}-3$. The NMR data as well as the sign of optical rotation of $\mathbf{1}$ were in good agreement with those reported for integrifolin and its derivatives. ${ }^{9,14,17,18)}$ Consequently, the structure of $\mathbf{1}$ was formulated as $3 \beta$-hydroxy- $8 \beta$ ( $p$-hydroxyphenylacetyloxy)-guaia-4(15),10(14),11(13)-trien$1 \alpha, 5 \alpha, 6 \beta, 7 \alpha \mathrm{H}-12,6$-olide or $8-O-p$-hydroxyphenylacetyl integrifolin, and it was named ixerochinolide.

Compound 2 had a molecular formula $\mathrm{C}_{37} \mathrm{H}_{40} \mathrm{O}_{13}$ as determined by HR-ESI-MS $\left(m / z 715.2369[\mathrm{M}+\mathrm{Na}]^{+}\right)$and ${ }^{13} \mathrm{C}$ NMR data. The IR and ${ }^{1} \mathrm{H}-\mathrm{NMR}$ spectral data revealed the presence of $\alpha$-methylene- $\gamma$-lactone ring similar to that of $\mathbf{1}$ as part of $c i s$-fused guaianolide skeleton. The presence of two ester groups of $p$-hydroxyphenylacetic acid was evident from the two sets of aromatic signals $\left(\mathrm{A}_{2} \mathrm{~B}_{2}\right)$ at $\delta 7.08,6.71$ and $6.98,6.68$ (each $2 \mathrm{H}, \mathrm{d}, J=8.5 \mathrm{~Hz}$ ) and two benzylic $\mathrm{CH}_{2}$ singlets at $\delta 3.54$ and 3.45. A $\beta$-D-glucosyl moiety was detected by the anomeric proton signal at $\delta 4.36(\mathrm{~d}, J=7.5 \mathrm{~Hz})$. The ${ }^{13} \mathrm{C}$-NMR data (Table 1) confirmed the existence of $\alpha$ methylene- $\gamma$-lactone ring $(\delta 171.4,136.7,122.2)$, two exomethylene $(\delta 117.6,112.2)$ as well as an anomeric carbon $(\delta$ 104.1). The two carbonyl signals located at $\delta 173.6,172.9$ combined with two benzylic $\mathrm{CH}_{2}$ signals at $\delta 41.4$ and 41.2 and four aromatic signals, each with double intensity at $\delta$ $131.4,131.3,116.3$ and 116.2 supported the presence of two

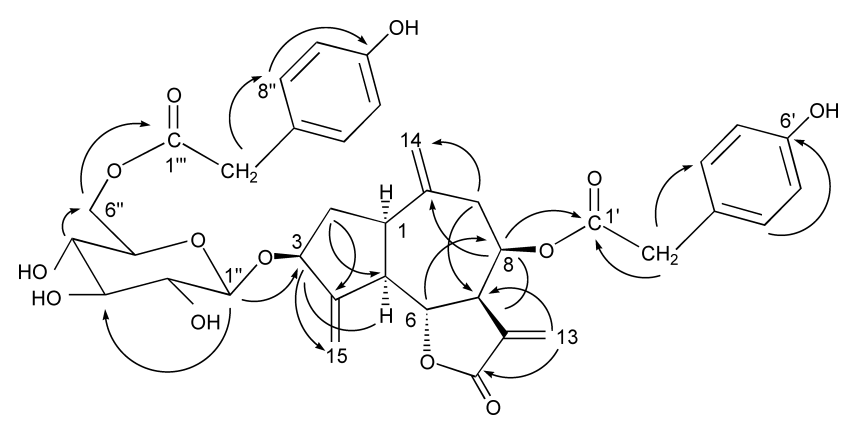

Fig. 1. Selected HMBC (Arrow) and NOESY (Curve) Correlations Observed for 2

Table 2. Results of Cytotoxic Activity of the Isolated Compounds against PC-3 Cells (SRB) $)^{a}$

$\begin{array}{ll}\text { Compound }(\mu \mathrm{g} / \mathrm{ml}) & \text { PC-3 } \\ \text { Ixerochinolide }(\mathbf{1}) & 1.6 \\ \text { 8-Epicrepioside } & >20 \\ \text { 8 } \beta \text {-Hydroxydehydro-zaluzanin } & 14.3 \\ \text { Lactucin } & 10.7 \\ 10 \alpha \text {-Hydroxy-10,14-dihydrodesacylcynaropicrin } & 13.3\end{array}$

a) The concentration of compound inhibiting $50 \%\left(\mathrm{IC}_{50}\right)$ of the growth of prostatetumor cells (PC-3) after $48 \mathrm{~h}$ drug exposure.

$p$-hydroxyphenylacetic acid esters. The low field shift of the oxygenated proton at $\delta 5.49(\mathrm{H}-8)$ and its HMBC correlation (Fig. 1) to the carbonyl at $\delta 172.9$ indicated the attachment of an ester moiety at C-8. The coupling constants together with the NOESY correlations between $\mathrm{H}-8 / \mathrm{H}-7 \alpha$ and $\mathrm{H}-3 / \mathrm{H}-$ $5 \alpha$ as well as the almost identical chemical shift values of $\mathrm{C}$ $3, \mathrm{C}-5, \mathrm{C}-6, \mathrm{C}-7$ and $\mathrm{C}-8$ (Table 1$)$ to those of $3 \beta-(\beta$-D-glucopyranosyloxy)-8 $\beta$-(4"-methoxyphenylacetoxy)-guaia$4(15), 10(14), 11(13)$-trien- $\alpha, 5 \alpha, 6 \beta, 7 \alpha \mathrm{H}-12,6$-olide ${ }^{19)}$ supported the proposed configuration at the former positions. The HMBC correlation between the anomeric signal at $\delta$ $4.36\left(\mathrm{H}-1^{\prime \prime}\right)$ and a carbon signal at $\delta 81.9$ (C-3) located the sugar moiety at $\mathrm{C}-3$. The second $p$-hydroxyphenylacetic acid ester was located at C- 6 " of the D-glucose moiety as deduced from the HMBC correlations between both signals of H- $6^{\prime \prime}$ ( $\delta$ $4.21,4.47)$ and the carbonyl signal of the ester at $\delta 173.6$ (Fig. 1). From the above-mentioned data, the structure of ixerochinoside (2) was established as $3 \beta$ - $\left(6^{\prime \prime}\right.$-phenylacetyloxy$\beta$-D-glucopyranosyloxy)-8 $\beta$-( $p$-hydroxyphenylacetyloxy)guaia-4(15),10(14),11(13)-trien-1 $\alpha, 5 \alpha, 6 \beta, 7 \alpha \mathrm{H}-12,6$-olide.

The known compounds $8 \beta$-hydroxydehydro-zaluzanin, ${ }^{15,17)}$ lactucin, ${ }^{20)} 10 \alpha$-hydroxy-10,14-dihydrodesacylcynaropicrin, ${ }^{21)}$ 8 -epicrepioside ${ }^{9}$ were identified through direct comparison with published data. The in vitro cytotoxicity of the isolated sesquiterpenes were evaluated against human prostate (PC-3) tumor cells. As illustrated in Table 2, compound 1 exhibited significant growth inhibition against PC-3 cells at $\mathrm{IC}_{50}$ of $1.6 \mu \mathrm{g} / \mathrm{ml}$. However, other compounds were very weak or inactive in this screen system.

\section{Experimental}

Optical rotations were recorded on a JASCO DIP-1000 polarimeter. IR and UV spectra were measured on Hitachi T-2001 and Hitachi U-3210 spectrophotometers, respectively. Low-resolution EI-MS and FAB-MS spectra were recorded on a VG Quattro 5022 mass spectrometer. High-resolution ESI-MS spectra were measured on a JEOL HX 110 mass spectrometer. The ${ }^{1} \mathrm{H}-,{ }^{13} \mathrm{C}-\mathrm{NMR}$, COSY, HMQC, HMBC, and NOESY spectra were recorded 
on a Bruker FT-300 spectrometer or on a Varian Unity INOVA 500 FT-NMR at $500 \mathrm{MHz}$ for ${ }^{1} \mathrm{H}$ and $125 \mathrm{MHz}$ for ${ }^{13} \mathrm{C}$, respectively, using TMS as internal standard. The chemical shifts are given in $\delta(\mathrm{ppm})$ and coupling constants in Hz. Silica gel 60 (Merck) was used for column chromatography (CC), and pre-coated silica gel plates (Merck, Kieselgel 60 F-254, $1 \mathrm{~mm}$ ) were used for preparative TLC.

Plant Material Ixeris chinensis NAKAI was collected in January 2003. A voucher specimen (TP 300-1) was deposited in the Institute of Marine Resources, National Sun Yat-sen University, Kaohsiung, Taiwan.

Extraction and Isolation The powdered whole plant (1900 g) was extracted three times with acetone $(3 \times 51)$. The concentrated extract was partitioned between EtOAc and $\mathrm{H}_{2} \mathrm{O}$ to produce an aqueous and an EtOAc layers. The latter, after removing the solvent under vacuum, was shaken four times with a mixture of $n$-hexane/MeOH/ $\mathrm{H}_{2} \mathrm{O}(4: 3: 1)$ in a separating funnel and the lower hydroalcoholic layer was concentrated to a syrup $(300 \mathrm{ml})$ and re-extracted with EtOAc $(4 \times 400 \mathrm{ml})$. The resulting EtOAc extract $(8.5 \mathrm{~g})$ was flash-chromatographed on silica gel using a gradient mixture of $\mathrm{CH}_{2} \mathrm{Cl}_{2} / \mathrm{MeOH}$ to furnish eight fractions. Fractions 3 (300 mg) was chromatographed on a silica gel column using a gradient of $n$-hexane/acetone followed by purification on silica gel PTLC using $n$-hexane/EtOAc $(3: 1)$ to yield $1(19 \mathrm{mg})$ and $8 \beta$-hydroxydehydrozaluzanin $(2 \mathrm{mg})$. Fraction $4(570$ $\mathrm{mg}$ ) was repeatedly chromatographed on a silica gel column using a gradient of $n$-hexane/acetone followed by PTLC on silica gel plates using $\mathrm{CH}_{2} \mathrm{Cl}_{2}$ $\mathrm{MeOH}(95: 5)$ to furnish lactucin $(3 \mathrm{mg})$ and $10 \alpha$-hydroxy-10,14-dihydrodesacylcynaropicrin $(2 \mathrm{mg})$. Fraction $5(750 \mathrm{mg})$ was chromatographed on a silica gel column using a gradient of $\mathrm{CH}_{2} \mathrm{Cl}_{2} / \mathrm{MeOH}$ to give $2(56 \mathrm{mg})$. Chromatography of fraction $7(4 \mathrm{~g})$ on silica gel column using a gradient of $\mathrm{CH}_{2} \mathrm{Cl}_{2} / \mathrm{MeOH}$ yielded 8-epicrepioside (1900 mg).

Compound (1): Colorless solid; $[\alpha]_{\mathrm{D}}-18.6^{\circ}(c=0.2, \mathrm{MeOH})$; IR (neat) $v_{\max } 3405$ br $(\mathrm{OH}), 2935(\mathrm{CH}), 1767$ (lactone), 1737 (ester), 1634 (double bond), 1517 (aromatic), 1248 and $1150(\mathrm{C}-\mathrm{O}) \mathrm{cm}^{-1} ;{ }^{1} \mathrm{H}-\mathrm{NMR}(300 \mathrm{MHz}$ $\left.\mathrm{CDCl}_{3}\right) \delta 2.87(1 \mathrm{H}, \mathrm{m}, \mathrm{H}-1), 2.24(1 \mathrm{H}, \mathrm{m}, \mathrm{H}-2 \mathrm{a}), 1.83(1 \mathrm{H}, \mathrm{m}, \mathrm{H}-2 \mathrm{~b}), 4.60$ $(1 \mathrm{H}$, br t $, J=7.0 \mathrm{~Hz}, \mathrm{H}-3), 2.85(1 \mathrm{H}$, br t $, J=9.6 \mathrm{~Hz}, \mathrm{H}-5), 4.40(1 \mathrm{H}, \mathrm{brt}$, $J=9.6 \mathrm{~Hz}, \mathrm{H}-6), 3.05(1 \mathrm{H}$, dddd, $J=9.6,3.3,3.1,1.8 \mathrm{~Hz}, \mathrm{H}-7), 5.43(1 \mathrm{H}, \mathrm{m}$, $\mathrm{H}-8), 2.54(1 \mathrm{H}, \mathrm{dd}, J=13.8,4.2 \mathrm{~Hz}, \mathrm{H}-9 \mathrm{a}), 2.43(1 \mathrm{H}, \mathrm{dd}, J=13.8,5.3 \mathrm{~Hz}, \mathrm{H}-$ 9b), $6.10(1 \mathrm{H}, \mathrm{d}, J=3.1 \mathrm{~Hz}, \mathrm{H}-13 \mathrm{a}), 5.39(1 \mathrm{H}, \mathrm{d}, J=3.3 \mathrm{~Hz}, \mathrm{H}-13 \mathrm{~b}), 5.06$ $(1 \mathrm{H}, \mathrm{s}, \mathrm{H}-14 \mathrm{a}), 4.81(1 \mathrm{H}, \mathrm{s}, \mathrm{H}-14 \mathrm{~b}), 5.46(1 \mathrm{H}, \mathrm{s}, \mathrm{H}-15 \mathrm{a}), 5.36(1 \mathrm{H}, \mathrm{s}, \mathrm{H}-$ 15b), $3.47\left(2 \mathrm{H}, \mathrm{s}, \mathrm{H}-2^{\prime}\right), 7.01\left(2 \mathrm{H}, \mathrm{d}, J=8.2 \mathrm{~Hz}, \mathrm{H}-4^{\prime}, 8^{\prime}\right), 6.76(2 \mathrm{H}, \mathrm{d}$, $\left.J=8.2 \mathrm{~Hz}, \mathrm{H}-5^{\prime}, 7^{\prime}\right) ;{ }^{13} \mathrm{C}-\mathrm{NMR}$ data: Table 1; FAB-MS $m / z 397[\mathrm{M}+\mathrm{H}]^{+}$; EI-MS (rel. int.): $m / z 378\left(\left[\mathrm{M}-\mathrm{H}_{2} \mathrm{O}\right]^{+}, 3\right) 244\left(\left[\mathrm{M}-\mathrm{C}_{8} \mathrm{H}_{6} \mathrm{O}_{3}\right]^{+}, 5\right), 226(8)$, 152 (24), 107 (100), 77 (60); HR-ESI-MS $m / z 419.1474[\mathrm{M}+\mathrm{Na}]^{+}$(Calcd for $\mathrm{C}_{23} \mathrm{H}_{24} \mathrm{O}_{6} \mathrm{Na}, 419.1471$ ).

Compound (2): Yellowish solid; $[\alpha]_{\mathrm{D}}-19.8^{\circ}(c=0.1, \mathrm{MeOH})$; IR (neat) $v_{\max } 3399$ br $(\mathrm{OH}), 2929(\mathrm{CH}), 1768$ (lactone), 1735 (ester), 1515 (aromatic), $1245 \mathrm{~cm}^{-1} ;{ }^{1} \mathrm{H}-\mathrm{NMR}\left(500 \mathrm{MHz}, \mathrm{CD}_{3} \mathrm{OH}\right) \delta 2.86(1 \mathrm{H}, \mathrm{m}, \mathrm{H}-1), 2.14$ (1H, ddd, $J=13.9,8.2,6.7 \mathrm{~Hz}, \mathrm{H}-2 \mathrm{a}), 1.83(1 \mathrm{H}, \mathrm{ddd}, J=13.9,6.5,6.1 \mathrm{~Hz}, \mathrm{H}-$ 2b), $4.40(1 \mathrm{H}, \mathrm{m}, \mathrm{H}-3), 2.77(1 \mathrm{H}, \mathrm{brt}, J=9.5 \mathrm{~Hz}, \mathrm{H}-5), 4.42(1 \mathrm{H}, \mathrm{t}$, $J=9.5 \mathrm{~Hz}, \mathrm{H}-6), 3.27(1 \mathrm{H}$, dddd, $J=9.5,3.3,3.3,2.2 \mathrm{~Hz}, \mathrm{H}-7), 5.49(1 \mathrm{H}$, ddd, $J=5.0,2.5,2.2 \mathrm{~Hz}, \mathrm{H}-8), 2.86(1 \mathrm{H}, \mathrm{m}, \mathrm{H}-9 \mathrm{a}), 2.55(1 \mathrm{H}, \mathrm{m}, \mathrm{H}-9 \mathrm{~b}), 6.04$ $(1 \mathrm{H}, \mathrm{d}, J=3.3 \mathrm{~Hz}, \mathrm{H}-13 \mathrm{a}), 5.45(1 \mathrm{H}, \mathrm{d}, J=3.3 \mathrm{~Hz}, \mathrm{H}-13 \mathrm{~b}), 5.02(1 \mathrm{H}, \mathrm{s}, \mathrm{H}-$ 14a), $4.75(1 \mathrm{H}, \mathrm{s}, \mathrm{H}-14 \mathrm{~b}), 5.42(1 \mathrm{H}, \mathrm{s}, \mathrm{H}-15 \mathrm{a}), 5.31(1 \mathrm{H}, \mathrm{s}, \mathrm{H}-15 \mathrm{~b}), 3.45$ $\left(2 \mathrm{H}, \mathrm{s}, \mathrm{H}-2^{\prime}\right), 6.98\left(2 \mathrm{H}, \mathrm{d}, J=8.5 \mathrm{~Hz}, \mathrm{H}-4^{\prime}, 8^{\prime}\right), 6.68\left(2 \mathrm{H}, \mathrm{d}, J=8.5 \mathrm{~Hz}, \mathrm{H}-5^{\prime}\right.$, $\left.7^{\prime}\right), 4.36\left(1 \mathrm{H}, \mathrm{d}, J=7.5 \mathrm{~Hz}, \mathrm{H}-1^{\prime \prime}\right), 3.25\left(1 \mathrm{H}, \mathrm{m}, \mathrm{H}-2^{\prime \prime}\right), 3.37\left(1 \mathrm{H}, \mathrm{m}, \mathrm{H}-3^{\prime \prime}\right)$, $3.30(1 \mathrm{H}, \mathrm{m}, \mathrm{H}-4), 3.76\left(1 \mathrm{H}, \mathrm{m}, \mathrm{H}-5^{\prime \prime}\right), 4.47\left(1 \mathrm{H}, \mathrm{m}, \mathrm{H}-6^{\prime \prime} \mathrm{a}\right), 4.21(1 \mathrm{H}, \mathrm{dd}$, $\left.J=12.5,6.0 \mathrm{~Hz}, \mathrm{H}-6^{\prime \prime} \mathrm{b}\right), 3.54\left(2 \mathrm{H}, \mathrm{s}, \mathrm{H}-2^{\prime \prime \prime}\right), 7.08$ (2H, d, $\left.J=8.5 \mathrm{~Hz}, \mathrm{H}-4^{\prime \prime \prime}, 8^{\prime \prime \prime}\right)$, $6.71\left(2 \mathrm{H}, \mathrm{d}, J=8.5 \mathrm{~Hz}, \mathrm{H}-5^{\prime \prime \prime}, 7^{\prime \prime \prime}\right) ;{ }^{13} \mathrm{C}-\mathrm{NMR}$ data: Table 1; FAB-MS $\mathrm{m} / \mathrm{z} 693$ $[\mathrm{M}+\mathrm{H}]^{+}$; HR-ESI-MS $m / z 715.2369[\mathrm{M}+\mathrm{Na}]^{+}\left(\right.$Calcd for $\mathrm{C}_{37} \mathrm{H}_{40} \mathrm{O}_{13} \mathrm{Na}$, 715.2367).

Cytotoxicity Assay $^{22}$ The human PC-3 (prostate) cancer cell line of the screening panel are grown in RPMI 1640 medium containing $5 \%$ fetal bovine serum and $2 \mathrm{~mm} \mathrm{~L}$-glutamine. Cells are inoculated into 96 well microtiter plates in $100 \mu \mathrm{g}$ at plating densities ranging from 5000 to 40000 cells/well depending on the doubling time of individual cell lines. After cell inoculation, the microtiter plates are incubated at $37{ }^{\circ} \mathrm{C}, 5 \% \mathrm{CO}_{2}, 95 \%$ air and $100 \%$ relative humidity for $24 \mathrm{~h}$ prior to addition of experimental drugs. After $24 \mathrm{~h}$, two plates of each cell line are fixed in situ with TCA, to represent a measurement of the cell population for each cell line at the time of drug addition. Experimental drugs are solubilized in dimethyl sulfoxide at 400 -fold the desired final maximum test concentration and stored frozen prior to use. At the time of drug addition, an aliquot of frozen concentrate is thawed and diluted to twice the desired final maximum test concentration with complete medium containing $50 \mu \mathrm{g} / \mathrm{ml}$ gentamicin. Additional four, 10 -fold or $1 / 2 \log$ serial dilutions are made to provide a total of five drug concentrations plus control. Aliquots of $100 \mu \mathrm{l}$ of these different drug dilutions are added to the appropriate microtiter wells already containing $100 \mu \mathrm{l}$ of medium, resulting in the required final drug concentrations. Following drug addition, the plates are incubated for an additional $48 \mathrm{~h}$ at $37^{\circ} \mathrm{C}, 5 \%$ $\mathrm{CO}_{2}, 95 \%$ air and $100 \%$ relative humidity. For adherent cells, the assay is terminated by the addition of cold TCA. Cells are fixed in situ by the gentle addition of $50 \mu \mathrm{l}$ of cold $50 \%(\mathrm{w} / \mathrm{v})$ TCA (final concentration, $10 \%$ TCA) and incubated for $60 \mathrm{~min}$ at $4{ }^{\circ} \mathrm{C}$. The supernatant is discarded, and the plates are washed five times with tap water and air-dried. Sulforhodamine B (SRB) solution $(100 \mu \mathrm{l})$ at $0.4 \%(\mathrm{w} / \mathrm{v})$ in $1 \%$ acetic acid is added to each well, and plates are incubated for $10 \mathrm{~min}$ at room temperature. After staining, unbound dye is removed by washing five times with $1 \%$ acetic acid and the plates are air dried. Bound stain is subsequently solubilized with $10 \mathrm{~mm}$ trizma base, and the absorbance is read on an automated plate reader at a wavelength of $515 \mathrm{~nm}$. Paclitaxel was used as standard.

Acknowledgments The authors are grateful to the National Science Council, Taipei, Taiwan, for financial support (Grant \# NSC 91-2320-B-110009). We thank Ms. Ho chao Lein and Yu shiu Ching, NSC Southern NMR and MS Instrument Center in the National Sun Yat-sen University, for measurement of NMR and MS spectra.

\section{References}

1) Kan W. S., "Pharmaceutical Botany," National Research Institute of Chinese Medicine, Taipei, Taiwan, 1981, p. 562.

2) Siedle B., Cisielski S., Murillo R., Loser B, Castro V., Klaas C. A., Hucke O., Labahn A., Melzig M. F., Merfort I., Bioorg. Med. Chem., 10, 2855-2861 (2002)

3) Dirsch V. M., Stuppner H., Ellmerer-Muller E. P., Vollmar A. M., Bioorg. Med. Chem., 8, 2747-2753 (2000).

4) Robles M., Aregullin M., West J., Rodriguez F., Planta Med., 61, 2855-2861 (1995).

5) Yuuya S., Hagiwara H., Suzuki T., Ando M., Yamada A., Suda K., Kataoka T., Nakai K., J. Nat. Prod., 62, 22-30 (1999).

6) Francois G., Passreiter C. M., Woerdenbag H. J., Van Looveren M., Planta Med., 62, 126-129 (1996).

7) Heilmann J., Wasescha M. R., Schmidt T. J., Bioorg. Med. Chem., 9, 2189-2194 (2001).

8) Zhang S., Wang J., Xue H., Deng Q., Xing F., Ando M., J. Nat. Prod., 65, 1927-1929 (2002)

9) Lee S. W., Chen Z. T., Chen C. M., Heterocycles, 38, 1933-1936 (1994).

10) Shiojima K., Suzuki H., Kodera N., Kubota K., Tsushima S., Ageta H., Chang H.-C., Chen Y.-P., Chem. Pharm. Bull., 42, 2193-2195 (1994).

11) Shiojima K., Suzuki H., Kodera N., Ageta H., Chang H.-C., Chen Y.P., Chem. Pharm. Bull., 44, 509-514 (1996).

12) Asada H., Miyase T., Fukushima S., Chem. Pharm. Bull., 32, 30363042 (1984).

13) Helal A. M., Nakamura N., Meselhy M. R., El-Fishawy A. M., Hattori M., Mahran G. H., Phytochemistry, 45, 551—554 (1997).

14) Nishimura K., Miyase T., Ueno A., Noro T., Kuroyanagi M., Fukushima S., Chem. Pharm. Bull., 33, 3361-3368 (1985).

15) Bohlmann F., Gupta R. K., Phytochemistry, 21, 1799-1800 (1982).

16) Santos S. M. B. P., Palma F. M. S. B., Urones J. G., Grande M., Phytochemistry, 27, 3672-3673 (1988).

17) Massanet G. M., Rodriguez-Luis F., Chozas C. V., Guerra F. M., Dorado J. M., Phytochemistry, 34, 1565-1567 (1993).

18) Massanet G. M., Collado I. G., Macias F. A., Luis F. R., Vergara C., Phytochemistry, 23, 912-913 (1984).

19) Zidorn C., Ellmerer-Muller E. P., Stuppner H., Phytochemistry, 50, 1061-1062 (1999).

20) Sarg T. M., Omar A. A., Khafagy S. M., Grenz M., Bohlmann F., Phytochemistry, 21, 1163 (1982).

21) Gonzalez A. G., Barrera J. B., Acosta J. C., Rosas F. E., Phytochemistry, 24, 1383-1384 (1985).

22) Kim H. M., Oh G. T., Han S. B., Hong D. H., Hwang B. Y., Kim Y. H., Lee J. J., Arch. Pharm. Res., 17, 100-103 (1994). 